\title{
PERAN PROFITABILITAS DALAM MEMODERASI PENGARUH STRUKTUR MODAL DAN KEBIJAKAN DIVIDEN TERHADAP NILAI PERUSAHAAN
}

\author{
Mislia Ambar Sari ${ }^{1}$, Lela Nurlaela Wati ${ }^{2}$, Bambang Rahardjo ${ }^{3}$ \\ ${ }^{1,3}$ STIE Kusuma Negara Jakarta, misliaas@gmail.com \\ ${ }^{2}$ STIE Muhammadiyah Jakarta, lela@ stiemj.ac.id
}

\begin{abstract}
ABSTRAK
Penelitian ini bertujuan untuk mengetahui pengaruh struktur modal dan kebijakan dividen terhadap nilai perusahaan dengan moderasi profitabilitas pada perusahaan food \& beverages. Sampel adalah perusahaan manufaktur Sub Sektor Food \& Beverages yang tercatat dalam Bursa Efek Indonesia periode 2014-2018, yang diambil dengan teknik purposive sampling. Teknik analisis yang digunakan adalah analisis regresi moderasi (MRA) menggunakan eviews 9. Hasil pengujian hipotesis menunjukkan bahwa variabel struktur modal (DER) berpengaruh positif dan signifikan terhadap nilai perusahaan (PBV), kebijakan dividen (EPS) berpengaruh positif dan signifikan terhadap nilai perusahaan (PBV), profitabilitas (ROA) memperkuat pengaruh struktur modal (DER) terhadap nilai perusahaan (PBV), namun profitabilitas (ROA) tidak memperkuat pengaruh kebijakan dividen (EPS) terhadap nilai perusahaan (PBV). Hasil ini menunjukkan bahwa semakin tinggi struktur modal yang dibiayai oleh hutang dan semakin besar dividen yang dibagikan kepada investor akan meningkatkan nilai perusahaan.
\end{abstract}

Kata Kunci : Struktur Modal, Kebijakan Dividen ,Profitabilitas , Nilai Perusahaan

\begin{abstract}
This study aims to determine the effect of capital structure and dividend policy on firm value by moderating profitability in food \& beverages companies. Samples are Food \& Beverages Sub Sector manufacturing companies listed on the Indonesia Stock Exchange in the 2014-2018 period, which were taken using purposive sampling technique. The analysis technique used is a moderation regression analysis (MRA) using eviews 9. The results of hypothesis testing show that the capital structure variable (DER) has a positive and significant effect on firm value (PBV), dividend policy (EPS) has a positive and significant effect on firm value ( PBV), profitability (ROA) strengthens the effect of capital structure (DER) on firm value (PBV), but profitability (ROA) does not strengthen the effect of dividend policy (EPS) on firm value (PBV). These results indicate that the higher the capital structure financed by debt and the greater the dividends distributed to investors, the higher the firm value.
\end{abstract}

Keywords: Capital Structure, Dividend Policy, Profitability Firm Value

Naskah diterima : 15-04-2020, Naskah dipublikasikan : 30-04-2020 


\section{PENDAHULUAN}

Perusahaan memiliki tujuan dalam menjalankan segala kegiatannya. Untuk menjalankan kegiatannya, maka perusahaan harus memiliki sumber dana. Perusahaan yang maju dan berkembang pesat akan mendapatkan dana yang berasal dari luar perusahaan yaitu dengan cara menerbitkan saham kepada masyarakat yang biasa disebut perusahaan go public. Dana yang diperoleh dari go public, umumnya digunakan untuk berbagai kebutuhan perusahaan seperti kebutuhan ekspansi, menambah modal kerja, membayar utang, peningkatan investasi di anak perusahaan, memperbaiki struktur permodalan, dan lain-lain (Fakhruddin, 2008: 1).

Sumber dana berasal dari 2 sumber, yakni sumber internal dan sumber eksternal. Sumber dana internal adalah dana yang berasal dari dalam perusahaan yaitu: Laba ditahan (laba yang tidak dibagikan sebagai dividen) dan penyusutan (depreciation), depreciation dimasukkan sebagai sumber dana karena dalam laporan laba rugi depresiasi merupakan biaya, padahal dananya tidak keluar dari perusahaan. Sumber dana eksternal merupakan dana yang berasal dari luar perusahaan antara lain: Utang dari supplier atau pihak lain atau LKNB, Utang Bank, Utang Obligasi, dan Modal sendiri yang berupa saham (Juhandi, 2007: 8). Sumber dana eksternal perusahaan go public yang paling banyak diminati oleh masyarakat adalah modal sendiri yang berupa saham. Saham dapat memberikan keuntungan yang besar dengan tingkat risiko yang besar pula, sebaliknya saham dapat juga berisiko kecil dengan keuntungan yang kecil pula. Investor harus melakukan analisis saham secara tepat dan benar untuk meminimalisir kerugian dalam berinvestasi. Ada dua cara investor menganalisis saham, yaitu analisis teknikal dan analisis fundamental.

Hermuningsih (2012:194) mengatakan bahwa salah satu aspek penting dari analisis fundamental adalah analisis laporan keuangan, karena dari situ dapat diperkirakan keadaan, atau posisi dan arah perusahaan. Analisis laporan keuangan menggunakan rasio keuangan yang dapat digunakan sebagai bahan pertimbangan dalam menentukan harga saham yang beredar di masyarakat. Jika harga saham yang ditawarkan ke masyarakat besar, maka nilai perusahaan tersebut juga meningkat. Perubahan harga saham diukur dari perubahan rasio harga saham terhadap nilai buku saham Aisjah (2012: 57). Nilai perusahaan mencerminkan tingkat kesejahteraan perusahaan tersebut. Semakin tinggi nilainya maka akan semakin tinggi tingkat kesejahteraan perusahaan tersebut (Maulana \& Wati, 2019).

Untuk melihat pergerakan niai perusahaan, dalam hal ini menggunakan proxy Price to Book Value (PBV) pada sub sektor food \& beverages di Indonesia selama 5 tahun terakhir di bursa efek Indonesia (BEI) sebagai berikut:

Tabel 1. Pergerakan PBV Tahun 2014-2018

\begin{tabular}{|c|c|c|c|c|c|}
\hline PERUSAHAAN & \multicolumn{5}{|c|}{ PBV } \\
\hline $\begin{array}{c}\text { FOOD \& } \\
\text { BEVERAGES (51) }\end{array}$ & $\mathbf{2 0 1 4}$ & $\mathbf{2 0 1 5}$ & $\mathbf{2 0 1 6}$ & $\mathbf{2 0 1 7}$ & $\mathbf{2 0 1 8}$ \\
\hline ADES & 2.73 & 1.82 & 1.53 & 1.23 & 1.13 \\
\hline ALTO & 1.40 & 1.40 & 1.50 & 2.03 & 2.26 \\
\hline BTEK & 16.99 & 24.85 & 4.71 & 0.41 & 0.38 \\
\hline BUDI & 0.45 & 0.26 & 0.00 & 0.35 & 0.35 \\
\hline CEKA & 0.81 & 0.31 & 0.90 & 0.85 & 0.84 \\
\hline DLTA & 7.53 & 0.10 & 3.96 & 3.21 & 3.43 \\
\hline ICBP & 5.62 & 4.79 & 2.70 & 5.11 & 5.37 \\
\hline INDF & 1.61 & 1.05 & 1.58 & 1.43 & 1.31 \\
\hline MLBI & 0.45 & 22.54 & 30.17 & 14.22 & 28.87 \\
\hline MYOR & 5.29 & 5.25 & 5.87 & 6.14 & 6.86 \\
\hline
\end{tabular}




\section{JURNAL AKUNTANSI, Vol. 9, No. 1, April (2020)}

\begin{tabular}{|c|c|c|c|c|c|} 
PSDN & 0.51 & 0.54 & 0.69 & 1.23 & 1.14 \\
\hline ROTI & 7.25 & 5.39 & 5.61 & 2.29 & 2.54 \\
\hline SKBM & 2.65 & 2.57 & 1.63 & 1.21 & 1.15 \\
\hline SKLT & 1.44 & 1.68 & 0.72 & 2.47 & 3.06 \\
\hline STTP & 4.65 & 3.92 & 3.58 & 4.12 & 2.98 \\
\hline ULTJ & 5.27 & 1.02 & 0.95 & 3.56 & 3.27 \\
\hline
\end{tabular}

Sumber data diolah dari: idx.co.id

Berdasarkan data diatas, untuk perkembangan nilai perusahaan yang terjadi pada masingmasing perusahaan food \& beverages mengalami gejolak yang tidak sama untuk setiap tahunnya. Perbedaan fluktuasi yang menyebabkan turunnya nilai perusahaan tidak bisa diprediksi. Misal, pada tahun 2018, dimana tahun yang terdekat untuk saat ini dengan rata-rata perusahaanperusahaan mengalami penurunan nilai perusahaan, seperti ADES, BTEK, INDF, STTP, ULTJ, sedangkan perusahaan lain mengalami peningkatan. Sehingga ini menjadikan alasan saya sebagai penulis untuk mengamati perubahan nilai perusahaan pada sub sektor food \& beverages di Indonesia.

Beberapa faktor penting yang menjadi tolak ukur untuk mengetahui nilai perusahaan, salah satunya dari struktur modal yang digunakan Juhandi (2008: 93). Struktur modal merupakan perimbangan jumlah utang jangka panjang, saham preferen, dan saham biasa. Untuk pengukuran drajat penggunaan utang atau menyatakan struktur modal suatu perusahaan yaitu dengan leverage Juhandi (2008: 101). Leverage ratio yaitu kemampuan perusahaan menjalankan aktivitasnya dengan menggunakan utang. Menurut Juhandi (2007:24), leverage ratio terdiri dari: debt ratio, total debt to equity ratio (debt to equity ratio), time interest earned ratio, leverage interest charge, total assets to net worth, dan long term debt to total equity. Pada penelitian ini, peneliti menggunakan faktor fundamental yakni debt to equity ratio atau DER. Debt to equity ratio (DER) merupakan rasio keuangan yang menghitung berapa besar suatu perusahaan dapat membayar atau melunasi hutangnya dari modal yang dimilikinya. Menurut Amanda, dkk (2012:2) debt to equity ratio (DER) yang tinggi menunjukkan bahwa perusahaan sangat bergantung pada pihak luar dalam mendanai kegiatan sehingga beban perusahaan juga akan meningkat.

Beberapa penelitian terdahulu menyatakan bahwa struktur modal berpengaruh positif dan signifikan terhadap nilai perusahaan yaitu Abidin, dkk (2016) Kohar dan Akramunnas (2017)

Akan tetapi pada penelitian yang dilakukan oleh Ika dan Shiddiq (2013), mendapatkan bahwa debt to equity ratio (DER) proksi dari struktur modal tidak memiliki pengaruh yang signifikan terhadap PBV proksi dari nilai perusahaan. Hal ini menjelaskan bahwa semakin besar DER yang dimiliki perusahaan yang diidentifikasikan dengan nilai utang yang besar tidak berpengaruh pada nilai perusahaan. Semakin tinggi nilai debt to equity ratio (DER) maka semakin tinggi suatu perusahaan membiayai modal dari hutang tersebut. Semakin tinggi hutang yang akan dijadikan modal perusahaan, maka akan mempengaruhi naik dan turunnya harga saham perusahaan. Dan karena perubahan harga saham, maka nilai perusahaan pun akan berubah.

Selain Struktur Modal, kebijakan dividen juga diduga berpengaruh terhadap nilai perusahaan. Kebijakan dividen merupakan keputusan keuangan yang dilakukan oleh perusahaan apakah laba yang didapatkan akan dibagikan kepada pemegang saham atau ditahan sebagai laba ditahan. Kebijakan dividen sering kali menimbulkan konflik kepentingan antara pihak manajemen perusahaan dengan pihak investor. Bird in the hand theory menyatakan bahwa investor lebih tertarik terhadap perusahaan yang membagikan dividen (Wiagustini, 2010:262). Pembagian dividen yang dilakukan perusahaan dianggap menjadi sinyal positif oleh para investor untuk menanamkan modal, karena investor lebih suka pada return yang pasti pada investasinya. Perusahaan yang membagikan dividen akan menarik minat investor untuk menanamkan modalnya. 
Dengan banyaknya investor yang membeli saham maka akan menaikkan harga saham sehingga meningkatkan nilai perusahaan.

Beberapa penelitian terdahulu menyatakan bahwa kebijakan dividen tidak berpengaruh signifikan terhadap nilai perusahaan, yang mana telah diteliti oleh Ulya (2014) dan Abdillah (2013). Berbanding terbalik dengan penelitian yang dilakukan Prastuti dan Sudiartha (2016) bahwa kebijakan dividen memiliki pengaruh signifikan terhadap nilai perusahaan dengan arah positif. Adanya pengaruh yang signifikan dari kebijakan dividen terhadap nilai perusahaan dengan arah positif berarti bahwa perusahaan dengan kebijakan dividen yang tinggi akan memiliki nilai yang tinggi pula.

Penentuan kekuatan dari masing-masing variabel yaitu struktur modal dan kebijakan dividen terhadap nilai perusahaan, penulis membuat moderasi yaitu profitabilitas. Profitabilitas adalah kemampuan perusahaan dalam memperoleh laba. Yaitu membandingkan ukuran tingkat efektivitas manajemen seperti ditunjukkan oleh laba yang dihasilkan dari penjualan dan dari pendapatan investasi Juhandi (2007). Profitabilitas dapat memperkuat atau memperlemah suatu perhitungan dividen yang diterima maupun hutang yang bertambah yang akan mempengaruhi harga saham suatu perusahaan. Jika harga saham menurun, maka minat dari calon investor pun menurun yang membahayakan nilai perusahaan itu sendiri.

Sedangkan untuk menambah keakuratan penelitian, penulis menambahkan variabel control yaitu firm size. Menurut Wati (2017), Firm size (ukuran perusahaan) adalah suatu ukuran yang menunjukkan besar kecilnya suatu perusahaan, yang bisa diukur dari total penjualan, ratarata tingkat penjualan, dan total aktiva (asset). Pada umumnya perusahaan besar memiliki total aktiva yang besar pula sehingga dapat menarik investor untuk menanamkan modalnya pada perusahaan tersebut dan akhirnya saham tersebut mampu bertahan pada harga yang tinggi”.

Berdasarkan uraian di atas, penelitian ini bertujuan untuk menguji pengaruh struktur modal dan kebijakan dividen dengan moderasi profitabilitas terhadap nilai perusahaan. Penelitian ini belum banyak dilakukan oleh peneliti sebelumnya karena menggunakan variable moderasi profitabilitas untuk melihat factor lain yaitu profitablitas yang dapat memperkuat pengaruh struktur modal dan kebijakan dividen terhadap nilai perusahaan. Penelitian ini mengisi celah peneliti sebelumnya (Abidin dkk, 2016; Kohar dan Akramunnas, 2017; Ulya, 2014; Abdillah, 2013).

\section{KAJIAN LITERATUR}

\section{Nilai Perusahaan}

Dari tujuan perusahaan tersebut diatas, dapat disimpulkan bahwa nilai perusahaan sangat berpengaruh bagi tujuan perusahaan itu sendiri untuk menghasilkan laba. Nilai perusahaan merupakan harga yang terbentuk seandainya perusahaan dijual. Bila nilai perusahaan semakin tinggi, berarti harga yang akan diterima oleh pemilik perusahaan menjadi makin besar. Tujuan ini tidak hanya merupakan kepentingan bagi para pemegang saham, tetapi memberikan manfaat bagi masyarakat dan lingkungan perusahaan. (Juhandi, 2007,5)

Nilai perusahaan dapat memberikan kemakmuran pemegang saham secara maksimum apabila harga saham perusahaan meningkat, semakin tinggi harga saham maka kesejahteraan pemegang sahampun meningkat (Wati et al, 2018). Nilai perusahaan menjadi sinyal positif bagi investor, bahwa nilai perusahaan yang tinggi mencerminkan kemakmuran pemegangan saham juga tinggi. Puspitaningtyas (2017: 173). Price to book value digunakan sebagai proksi dari nilai perusahaan karena keberadaan price to book value sangat penting bagi investor untuk menentukan strategi investasi di pasar modal. Menurut Sugiono dan Untung (2016: 70), bahwa suatu perusahaan yang memiliki manajemen baik makas diharapkan PBV dari perusahaan tersebut, setidaknya adalah satu atau dengan kata lain diatas dari nilai buku. Jika PBV perusahaan dibawah satu, maka kita dapat menilai bahwa harga saham tersebut adalah dibawah nilai buku (under value) Hal ini menggambarkan nilai saham perusahaan lebih besar daripada nilai buku perusahaan. Harga 
saham yang tinggi membuat nilai perusahaan juga tinggi. Nilai perusahaan yang tinggi akan membuat pasar percaya tidak hanya pada kinerja perusahaan saat ini namun juga pada prospek perusahaan di masa depan. Secara sistematis price to book value (PBV) dapat dihitung dengan rumus sebagai berikut Sugiono dan Untung (2016: 70)

$$
\mathrm{PBV}=\frac{\text { Harga Pasar persaham }}{\text { Nilai Buku persaham }}
$$

Keterangan:

$\mathrm{PBV}=$ Price Book Value

Nilai buku saham (book value per share) dihitung dengan:

$$
\mathrm{BV}=\frac{\text { Total Ekuitas }}{\text { Jumlah Saham Yang Beredar }}
$$

Keterangan:

$\mathrm{BV}=$ Book Value (nilai buku persaham)

\section{Struktur Modal}

Struktur modal atau kapitalisasi perusahaan adalah pembiayaan permanen yang terdiri dari utang jangka panjang, saham preferen dan ekuitas saham biasa. Struktur modal suatu perusahaan merupakan sebagian dari struktur keuangannya, Brigham \& Houston dalam Aisjah (2012: 35) memandang struktur modal dalam pengertian kecukupan menyeluruh serta komposisinya, dan juga dalam pengertian rasio utang terhadap kekayaan atau dinamakan leverage. Struktur modal merupakan perimbangan jumlah utang jangka panjang, saham preferen, dan saham biasa. Struktur keuangan adalah perimbangan antara total utang dengan modal sendiri. Jadi struktur modal merupakan bagian dari struktur keuangan Juhandi (2008: 93).

Salah satu ratio yang digunakan dalam perhitungan rasio keuangan yaitu leverage ratio. Menurut Juhandi (2007:24) leverage ratio (rasio solvabilitas) yaitu mengukur hingga sejauh mana perusahaan dibiayai oleh utang. Perusahaan yang utangnya lebih kecil dibandingkan asetnya disebut solvable, bila sebaliknya disebut insovable. Salah satu leverage ratio proksi dari struktur modal yang dapat dihitung dari modal yang dimilikinya yaitu Debt to Equity Ratio (DER). Menurut Hantono (2018: 13) debt to equity ratio (DER) adalah rasio yang menunjukkan sejauh mana modal sendiri menjamin seluruh utang. Rasio ini dapat dibaca sebagai perbandinganan antara dana pihak luar dengan dana pemilik perusahaan. debt to equity ratio (DER) merupakan perbandingan antara total hutang yang dimiliki perusahaan dengan total ekuitasnya.

$$
\text { Debt to Equity (DER) }=\frac{\text { TOT AL UT ANG }}{\text { TOTAL MODAL SENDIRI }}=\frac{\text { TOTAL DEBT }}{\text { TOTAL EQUITY }}
$$

\section{Kebijakan Dividen}

Kebijakan dividen merupakan keputusan apakah laba yang diperoleh perusahaan akan dibagikan kepada pemegang saham sebagai deviden atau akan menjadi laba ditahan untuk mendanai investasi, sebagian laba untuk dividen dan sebagian laba untuk laba ditahan. Keputusan membayar dividen yang besar berarti menahan laba sedikit sehingga jika ada ekspansi perusahaan mengandalkan sumber dana exsternal. Sebaliknya dengan keputusan pembayaran dividen yang kecil berarti menahan laba yang lebih besar yang merupakan sumber dana internal (internal financing) yang dapat digunakan untuk ekspansi perusahaan Juhandi (2008:41).

Dalam menjadi pemegang saham sebuah perusahaan maka para pemegang saham menginginkan keuntungan yang bias didapat jika perusahaan mendapatkan laba. Salah satu cara menghitung keuntungan atas saham yang didapatkan oleh para pemegang saham perusahaan yaitu earning per share (EPS). Menurut Hilmi dkk (2016: 2) earning per share (EPS) adalah 
perbandingan antara keuntungan bersih setelah pajak yang diperoleh emiten dengan jumlah saham yang beredar. Sedangkan Hantono (2018: 12) mengatakan bahwa earning per share (EPS) merupakan rasio laba per lembar saham atau disebut juga rasio nilai buku merupakan rasio untuk mengukur keberhasilan manajemen dalam mencapai keuntungan bagi pemegang saham. Earning per share (EPS) adalah perbandingan antara laba bersih setelah pajak pada satu tahun buku dengan jumlah saham yang diterbitkan. Earning per share (EPS) dapat dihitung dengan:

$$
\text { Laba per lembar saham biasa }=\frac{\text { Laba Saham Biasa }}{\text { Saham Biasa Yang Beredar }}
$$

\section{Profitabilitas (ROA)}

Return On Assets merupakan salah satu rasio profitabilitas yang mengukur efektifitas perusahaan dalam menghasilkan laba dari aktiva yang digunakan (Wati et al., 2019). Tingkat ROA bergantung pada pengelolaan asset perusahaan oleh manajemen yang menggambarkan efisiensi dari operasional perusahaan. Profitabilitas adalah hasil akhir dari sejumlah kebijakan dan keputusan manajemen perusahaan. Perusahaan yang memiliki tingkat profitabilitas yang tinggi akan diminati sahamnya oleh investor, sehingga, dengan demikian profitabilitas dapat mempengaruhi nilai perusahaan. Menurut Mardiyati (2012), profitabilitas memiliki pengaruh yang positif signifikan terhadap nilai perusahaan. Profit yang tinggi akan memberikan indikasi prospek perusahaan yang baik sehingga dapat memicu investor untuk ikut meningkatkan permintaan saham. Permintaan saham yang meningkat akan menyebabkan nilai perusahaan yang meningkat. Oktaviani dan Mulya (2018), menyatakan bahwa Return On Assets merupakan rasio untuk mengukur profitabilitas perusahaan dengan mengukur kemampuan perusahaan dalam memanfaatkan asetnya untuk memperoleh laba. Rumus Return On Assets adalah sebagai berikut:

$$
\text { Return On Asset }=\frac{\text { Laba Bersih }}{\text { Total Asset }}
$$

\section{Variabel Kontrol}

Size

Size perusahaan dapat dilihat dari total asset yang dimiliki oleh perusahaan yang dapat dipergunakan untuk kegiatan operasi perusahaan. Perusahaan dengan total asset yang besar akan lebih memudahkan manajemen dalam mempergunakan asset perusahaan tersebut, jika dilihat dari sisi manajemen kemudahan yang dimilikinya dalam mengendalikan perusahaan akan meningkatkan nilai perusahaan.

Ukuran perusahaan (size) menggunakan nilai buku dari total aset atau total aktiva sebagai proksi size. Size digunakan untuk kontrol atas struktur modal (DER) dan kabijakan dividen (EPS) terhadap niali perushaaan (PBV). Size digunakan sebagai variabel kontrol atas Struktur modal Rasio ini juga digunakan dalam penelitian Paramu dalam Indrajaya, dkk (2011:12) dalam Viandita (2013), "mengingat nilai aktiva perusahaan yang besar maka dalam proses perhitungan nilai total aktiva dihitung dalam jutaan rupiah serta ditransformasikan ke dalam bentuk logaritma natural (Ln). Wati et al. (2019) memformulasikan proksi size jsebagai berikut":

Size $=$ Ln Total Assets

Keterangan :

Ln : Logaritma dari Total Aset 


\section{Pengembangan Hipotesis}

Teori yang berhubungan dengan keputusan pendanaan yaitu teori Modiglani \& Miller (MM). bahwa bagaimanapun pembagian struktur modal antara utang dan equity selalu terdapat perlindungan atas nilai investasi total perusahaan tergantung dari keuntungan dan risiko, maka nilai perusahaan tidak berubah walaupun struktur berubah Juhandi (2008: 98). Menurut Teori Mogdiliani dan Miller, nilai perusahaan ditentukan oleh struktur modal. Struktur modal menciptakan kebijakan hutang yang mana sangat sensitif terhadap perubahan nilai perusahaan. Semakin tinggi proporsi utang maka semakin tinggi harga saham, namun pada titik tertentu peningkatan utang akan menurunkan nilai perusahaan karena manfaat yang diperoleh dari penggunaan utang lebih kecil daripada biaya yang ditimbulkannya.

Menurut Arviansyah (2013) dalam Oktaviani dan Mulya (2018) yaitu semakin besar utang maka nilai perusahaan akan menurun. Perusahaan harus mampu menentukan besarnya utang, karena dengan adanya utang sampai batas tertentu akan dapat meningkatkan nilai perusahaan. Jika jumlah utang telah melewati batas tertentu nilai perusahaan justru akan menurun. Hal tersebut diakibatkan karena adanya beban yang harus ditanggung oleh perusahaan akibat dari penggunaan utang tersebut. Penelitian terdahulu menyatakan bahwa struktur modal berpengaruh positif dan signifikan terhadap nilai perusahaan yaitu Abidin, dkk (2014), Kohar dan Akramunnas (2017).

Dari penelitian tersebut berarti tinggi ataupun rendahnya utang perusahaan, nilai suatu perusahaan akan berubah dengan tingkatan tertentu. Berdasarkan penjelasan di atas dirumuskan hipotesis pertama sebagai berikut:

\section{H1: Struktur modal berpengaruh positif terhadap nilai perusahaan.}

Teori yang berkaitan dengan kebijakan dividen yaitu dividen tidak relevan, menurut Myron Gordon dan John Lintner dalam Eugane F Brigham \& Joel F Houston (2007:480) dalam Mardiyati (2012) mengatakan dividen lebih pasti daripada perolehan modal, disebut juga dengan teori bird in the hand, yaitu kepercayaan bahwa pendapatan memiliki nilai lebih tinggi bagi investor daripada capital gains, teori ini mengasumsikan bahwa dividen lebih pasti daripada pendapatan modal.

Gunawan et.al (2018), Prastuti dan Sudiartha (2016) bahwa kebijakan dividen memiliki pengaruh signifikan terhadap nilai perusahaan dengan arah positif. Adanya pengaruh yang signifikan dari kebijakan dividen terhadap nilai perusahaan dengan arah positif berarti bahwa perusahaan dengan kebijakan dividen yang tinggi akan memiliki nilai yang tinggi pula. Berdasarkan uraian di atas, maka dibuat hipotesis kedua berikut ini:

\section{H2 : Kebijakan Dividen berpengaruh positif terhadap nilai perusahaan.}

Rasio profitabilitas adalah sekelompok rasio yang menunjukkan gabungan efek-efek dari likuiditas, manajemen aktiva, dan hutang pada hasil-hasil operasi Brigham dan Houston (2003: 107) dalam Mardiyati (2012). Rasio profitabilitas mengukur kemampuan perusahaan dalam menghasilkan keuntungan dari kegiatan bisnis yang dilakukan. Hasilnya, investor dapat melihat seberapa efisien perusahaan menggunakan asset dan dalam melakukan operasinya untuk menghasilkan keuntungan. Rasio profitabilitas merupakan hasil akhir dari sejumlah kebijakan dan keputusan yang dilakukan oleh perusahaan. Semakin besar profitabilitas perusahaan maka perusahaan akan menggunakan keuntungannya sebagai laba ditahan dan memperkuat struktur modal perusahaan sehingga berdampak positif terhadap nilai perusahaan. Berdasarkan uraian di atas, maka dibuat hipotesis ketiga berikut ini:

\section{H3: Profitabilitas mampu memperkuat pengaruh struktur modal terhadap nilai perusahaan.}

Van Horne dan Wachowicz (2005:3) dalam Oktaviani dan Mulya (2018) mengemukakan bahwa kebijakan dividen adalah bagian yang tidak terpisahkan dalam keputusan pendanaan perusahaan. Rasio pembayaran dividen menentukan jumlah laba yang dapat ditahan dalam 
perusahaan sebagai sumber pendanaan, akan tetapi dengan menahan laba saat ini dalam jumlah yang lebih besar, berarti perusahaan memiliki lebih sedikit uang yang akan tersedia bagi pembayaran dividen saat ini sehingga pada akhirnya akan berdampak terhadap nilai perusahaan. Ini didukung oleh penelitian terdahulu Oktaviani dan Mulya (2018) yang menyatakan bahwa kebijakan dividen dimoderasi profitabilitas secara parsial berpengaruh signifikan terhadap nilai perusahaan.

\section{H4: Profitabilitas mampu memoderasi pengaruh kebijakan dividen terhadap nilai perusahaan.}

\section{Kerangka Pikir}

Berdasarkan uraian di atas, dapat dibuat suatu kerangka pemikiran teoritis yang menggambarkan variabel-variabel yang mempengaruhi nilai perusahaan yaitu:
Variabel Independen
Variabel Moderasi
Variabel Dependen

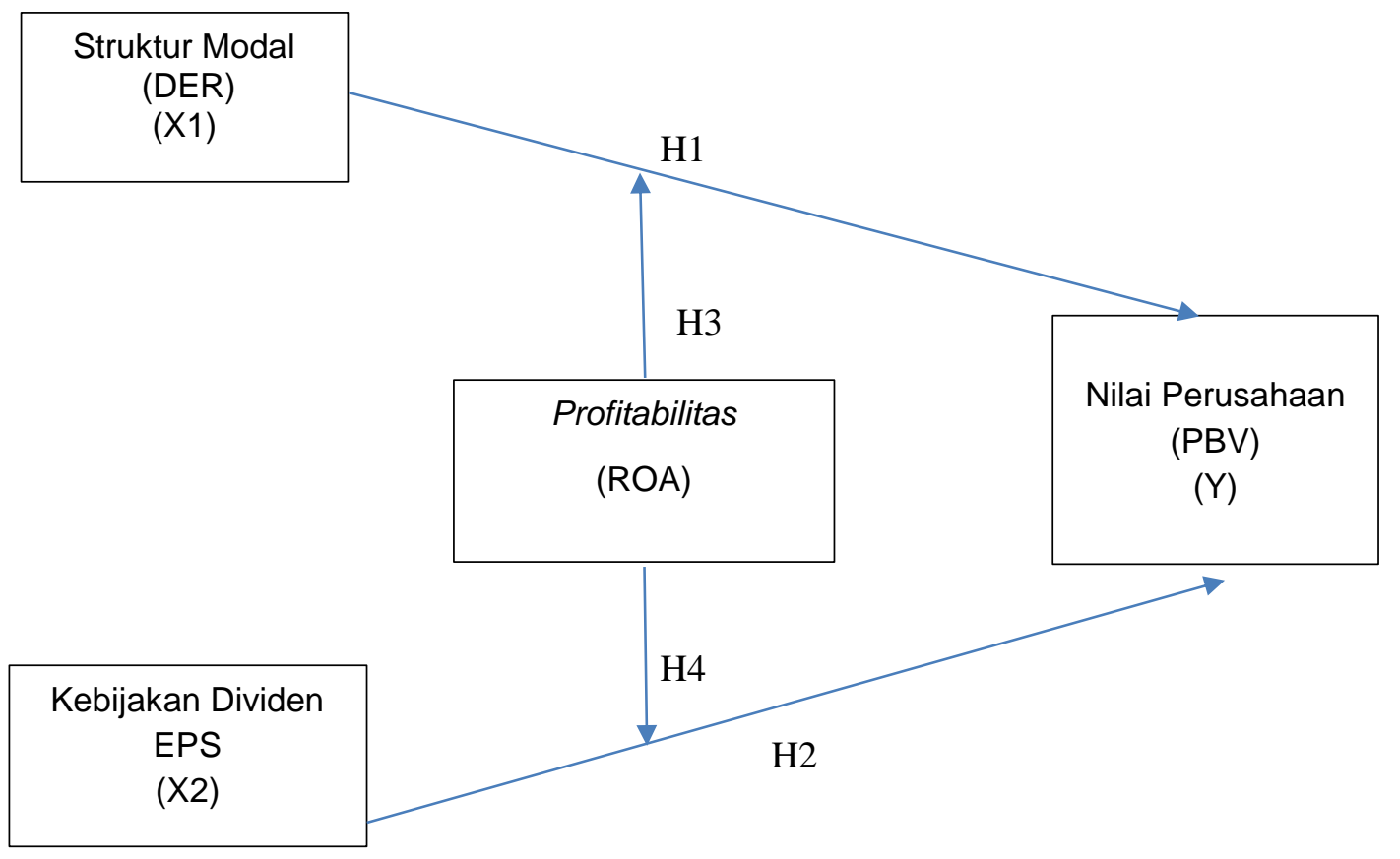

\section{Gambar 1. Kerangka Pikir}

\section{METODE PENELITIAN}

Penelitian ini menggunakan sample perusahaan manufaktur sub sektor food \& beverages yang mengeluarkan annual report dari tahun 2014-2018. Perusahaan manufaktur khususnya yang berkonsentrasi pada food \& beverages dan telah terdatar di bursa efek Indonesia (BEI) dan merupakan salah satu sektor yang berpengaruh pada kehidupan manusia. Kebutuhan manusia akan makanan dan minuman membuat peranan dari sektor food \& beverages terus berkembang untuk memenuhi kecukupan pangan masyarakat. Jumlah perusahaan manufaktur sub sektor food \& beverages tahun 2014-2018 memiliki populasi dalam penelitian ini sejumlah 24 perusahaan food \& beverages, namun setelah melewati teknik purposive sampling yang terpilih sebagai penelitian sejumlah 16 perusahaan sebagai berikut: 
Tabel 2. Hasil Pengambilan Sample Penelitian

\begin{tabular}{|c|l|c|}
\hline NO & \multicolumn{1}{|c|}{ Keterangan } & Jumlah Sampel \\
\hline 1 & $\begin{array}{l}\text { Perusahaan food \& beverages yang terdaftar di Bursa } \\
\text { Efek Indonesia (BEI) 2014-2018 }\end{array}$ & 24 \\
\hline 2 & $\begin{array}{l}\text { Perusahaan food \& beverages yang tidak } \\
\text { mempublikasikan Laporan Keuangannya secara } \\
\text { lengkap selama periode 2014-2018 } \\
\text { (AISA dan DAVO) }\end{array}$ & $\begin{array}{l}\text { Perusahaan food \& beverages yang mempublikasikan } \\
\text { laporan keuangannya selama 5 tahun berturut-turut } \\
\text { periode 2014-2018 } \\
\text { (CAMP, CLEO, GOOD, HOKI, PANI, PCAR) }\end{array}$ \\
\hline \multicolumn{2}{|c}{ Sampel final } & 16 \\
\hline
\end{tabular}

Sumber: Data sampel yang diolah

Model persamaan regresi data panel dalam penelitian ini adalah sebagai berikut:

$\mathrm{Y}=\alpha+\beta_{1} \mathrm{X}_{1}+\beta_{2} \mathrm{X}_{2}+\beta_{3} \mathrm{X}_{3}+\beta_{4} \mathrm{X}_{4}+e$

Keterangan:

$\mathrm{Y}=$ nilai perusahaan $(\mathrm{PBV})$

$\alpha \quad=$ konstanta

$\mathrm{X}_{1} \quad=$ struktur modal (DER)

$\mathrm{X}_{2} \quad=$ kebijakan dividen (EPS)

$\mathrm{X}_{3} \quad=$ profitabilitas $(\mathrm{ROA})$ memoderasi struktur modal (DER)

$\mathrm{X}_{4} \quad=$ profitabilitas $(\mathrm{ROA})$ memoderasi kebijakan dividen (EPS)

e $\quad$ Error

\section{ANALISIS DATA DAN PEMBAHASAN}

Tabel 3. Deskripsi Variabel Penelitian

\begin{tabular}{|c|c|c|c|c|c|c|c|}
\hline & PBV & C & DER & EPS & ROA*DER & ROA*EPS & SIZE \\
\hline Mean & 4.038000 & 1.000000 & 1.136500 & 1034.589 & 8.244953 & 29113.93 & 6.426625 \\
\hline Median & 2.145000 & 1.000000 & 1.050000 & 81.35000 & 4.534850 & 687.7829 & 6.325000 \\
\hline Maximum & 30.17000 & 1.000000 & 5.200000 & 37851.57 & 107.9589 & 1348651. & 7.980000 \\
\hline Minimum & 0.000000 & 1.000000 & 0.160000 & -32.36 & -12.4916 & 0.012500 & 5.520000 \\
\hline Std. Dev. & 5.960280 & 0.000000 & 0.817141 & 4804.931 & 18.11427 & 162241.8 & 0.616595 \\
\hline Skewness & 3.044067 & NA & 2.565928 & 6.436576 & 3.686056 & 7.228902 & 1.021596 \\
\hline Kurtosis & 12.13512 & NA & 12.85158 & 46.52927 & 17.48475 & 57.21418 & 3.354006 \\
\hline & & & & & & & \\
\hline Jarque-Bera & 401.7193 & NA & 411.2986 & 6868.383 & 880.5203 & 10494.02 & 14.33317 \\
\hline Probability & 0.000000 & NA & 0.000000 & 0.000000 & 0.000000 & 0.000000 & 0.000772 \\
\hline & & & & & & & \\
\hline Sum & 323.0400 & 80.00000 & 90.92000 & 82767.15 & 659.5962 & 2329114. & 514.1300 \\
\hline Sum Sq. Dev. & 2806.470 & 0.000000 & 52.74982 & $1.82 \mathrm{E}+09$ & 25922.01 & $2.08 \mathrm{E}+12$ & 30.03499 \\
\hline & & & & & & & \\
\hline Observations & 80 & 80 & 80 & 80 & 80 & 80 & 80 \\
\hline
\end{tabular}


Berdasarkan hasil statistik deskriptif variabel penelitian, dapat diketahui gambaran dari masing-masing variabel dependen dan independen sebagai berikut:

Berdasarkan tabel 3 dapat dilihat nilai terendah (minimum) nilai perusahaan (PBV) sebesar 0.000000 dicapai oleh Budi Starch \& Sweetener Tbk pada annual report tahun 2016. Nilai tertinggi (maximum) sebesar 30.17000 dicapai oleh Multi Bintang Indonesia Tbk pada annual report tahun 2016. Rata-rata (mean) sebesar 4.038000 dan standar deviasi sebesar 5.960280. Nilai teredah (minimum) struktur perusahaan (DER) 0.160000 dicapai oleh Ultrajaya Milk Industry and Trading Company Tbk dalam penelitian annual report pada tahun 2018. Nilai tertinggi (maximum) sebesar 5.200000 dicapai oleh Bumi Teknokultura Unggul Tbk dalam penelitian annual report pada annual report tahun 2015. Rata-rata (mean) 1.136500 dan standar devisiasi sebesar 0.817141. Nilai terendah (minimum) kebijakan dividen (EPS) sebesar -32.36000 dicapai oleh Prashida Aneka Niaga Tbk dalam penelitian pada annual report tahun 2018. Nilai tertinggi (maximum) sebesar 37851.57 dicapai oleh Multi Bintang Indonesia Tbk dalam penelitian pada annual report tahun 2014. Rata-rata (mean) 1034.589 dan standar devisiasi sebesar 4804.931. Nilai terendah (minimum) struktur modal (DER) dengan moderasi profitabilitas (ROA) sebesar-12.49160 dicapai oleh Prashida Aneka Niaga Tbk dalam penelitian pada annual report tahun 2018. Nilai tertinggi (maximum) sebesar 107.9589 dicapai oleh Multi Bintang Indonesia Tbk dalam penelitian pada annual report tahun 2014. Rata-rata (mean) 8.244953 dan standar devisiasi sebesar 18.11427. Nilai terendah (minimum) struktur modal (DER) dengan moderasi profitabilitas (ROA) sebesar 0.012500 dicapai oleh Bumi Teknokultura Unggul Tbk dalam penelitian pada annual report tahun 2015. Nilai tertinggi (maximum) sebesar 1348651 dicapai oleh Multi Bintang Indonesia Tbk dalam penelitian pada annual report tahun 2014. Rata-rata (mean) 29113.93 dan standar devisiasi sebesar 162241.8.

Tabel 4. Hasil Pengujian Model Penelitian

$\mathrm{PBV}=\alpha+\beta 1 \mathrm{DER}_{\mathrm{it}}+\beta 2 \mathrm{EPS}_{\mathrm{it}}+\beta 3 \mathrm{DER}_{\mathrm{it}} * \mathrm{ROA}_{\mathrm{it}}+\beta 4 \mathrm{EPS}_{\mathrm{it}} * \mathrm{ROA}_{\mathrm{it}}+\beta 5 \mathrm{SIZE}_{\mathrm{it}}+e$

\begin{tabular}{cccccc}
\hline Variabel & Prediksi & Main Model & Hipotesis & Robust & Hipootesis \\
\hline c & & 2.07 & & -2.07 & \\
DER & $\beta^{+}$ & 3.7926 & didukung & 3.866 & didukung \\
& & $(7.2393)$ & & $(7.7183)$ & \\
EPS & $\beta^{+}$ & $0.0015^{* * *}$ & didukung & $0.0016^{* * *}$ & didukung \\
& & $(-3.3243)$ & & $(3.3158)$ & \\
ROA*DER & \multirow{2}{*}{$\beta^{+}$} & $0.2572^{* * *}$ & didukung & $0.2607 * *$ & didukung \\
& & $(7.7202)$ & & $(7.8841)$ & \\
ROA*EPS & \multirow{2}{*}{$\beta^{+}$} & $-7.12 \mathrm{E}^{* * *}$ & tidak & $-7.26 \mathrm{E}^{* * *}$ & tidak \\
& & $(-4.9291)$ & didukung & $(-4.8623)$ & didukung \\
Size & & -0.626 & didukung & - & - \\
& & $(-0.7224)$ & & - & - \\
& & & & & \\
$\mathbf{R}^{2}$ & & $60.71 \%$ & & $60.85 \%$ & \\
Adj R & & $58.06 \%$ & & $58.76 \%$ & \\
F-Statistik & & $22.87 \%$ & & $29.14 \%$ & \\
\hline
\end{tabular}

Sumber: Data diolah 2019 
Pengujian Hipotesis secara parsial dilakukan dengan membandingkan $t_{\text {statistik }}$ dengan $t_{\text {tabel }}$ ataupun dengan melihat nilai signifikan. Koefisien regresi yang diperoleh dari pengaruh variabel struktur modal (DER) terhadap nilai perusahaan (PBV) adalah sebesar 3.7926 dengan nilai $\mathrm{t}_{\text {statistik }}$ $7.2393>1.96$, pada taraf signifikansi $\alpha=0.05(5 \%)$ dengan nilai signifikansi $0.0000<0.05$ yang menyatakan bahwa terdapat pengaruh positif dan signifikan antara struktur modal (DER) terhadap nilai perusahaan (PBV). Nilai 3.7926 pada koefisien regresi menunjukkan bahwa setiap struktur modal (DER) naik 1 maka nilai perusahaan (PBV) akan naik sebesar 3.7926. Begitu pula sebaliknya, jika struktur modal (DER) turun 1 maka nilai perusahaan (PBV) akan turun sebesar 3.7926. Hasil penelitian ini mendukung hipotesis pertama yang dilakukan oleh Oktaviani dan Mulya (2018) dimana struktur modal (DER) berpengaruh positif dan signifikan terhadap nilai perusahaan (PBV). Semakin besar struktur modal dibiayai oleh hutang maka akan meningkatkan nilai perusahaan. Hasil ini mendukung teori Modigliani Miller dimana struktur modal menciptakan kebijakan hutang yang mana sangat sensitif terhadap perubahan nilai perusahaan. Semakin tinggi proporsi utang maka semakin tinggi harga saham, namun pada titik tertentu peningkatan utang akan menurunkan nilai perusahaan karena manfaat yang diperoleh dari penggunaan utang lebih kecil daripada biaya yang ditimbulkannya.Hasil penelitian ini juga mendukung penelitian yang dilakukan oleh Abidin, dkk (2014), Mardiyati, dkk (2012), Kohar dan Akramunnas (2017), Prasetia, dkk (2014), Sartini dan Purbawangsa (2014), Gunawan et. al (2018) bahwa terdapat pengaruh positif antara struktur modal dengan nilai perusahaan.

Hasil pengujian hipotesis kedua pada tabel 4 di atas mendukung hipotesis, dimana kebijakan dividen berpengaruh positif signifikan terhadap nilai perusahaan. Hasil penelitian ini mendukung teori relevan The bird in the hand theory pemberian dividen kepada investor merupakan signal positif yang berdampak terhadap nilai perusahaan.Hasil penelitian ini juga mendukung penelitian yang dilakukan oleh Hasil ini mendukung penelitian yang dilakukan oleh Sartini dan Purbawangsa (2014), Sugiarto (2011), Rehman (2016), Prastuti dan Sudiartha (2016), Putra dan Lestari (2016) gunawanbahwa terdapat pengaruh positif antara kebijakan dividen dengan nilai perusahaan.

Hasil pengujian hipotesis ketiga pada tabel 4 di atas mendukung hipotesis, dimana profitabilitas mampu memperkuat pengaruh struktur modal terhadap nilai perusahaan. Hasil penelitian ini mendukung penelitian yang dilakukan oleh Mardiyati dkk (2012) dimana profitabilitas (ROA) memperkuat pengaruh struktur modal (DER) terhadap nilai perusahaan (PBV). Dari hasil pengujian diketahui bahwa interaksi antara struktur modal (DER) dan profitabilitas (ROA) mempu memberikan pengaruh positif terhadap nilai perusahaan. Pendanaan dari utang yang dimiiiliki oleh perusahan selanjutnya akan diolah menjadi operasional perusahaan maupun penambahan aset perusahaan guna mencapai tujuan dari perusahaan yaitu meningkatkan laba perusahaan. Maka profitabilitas memperkuat pengaruh struktur modal terhadap nilai perusahaan.

Hasil pengujian hipotesis keempat pada tabel 4 di atas tidak mendukung hipotesis, dimana profitabilitas tidak mampu memperkuat pengaruh kebijakan dividen terhadap nilai perusahaan. Hasil penelitian ini tidak mendukung penelitian yang dilakukan oleh Oktaviani dan Mulya (2018) dimana profitabilitas (ROA) tidak memperkuat pengaruh kebijakan dividen (EPS) terhadap nilai perusahaan (PBV). Rasio pembayaran dividen menentukan jumlah laba yang dapat ditahan dalam perusahaan sebagai sumber pendanaan, akan tetapi dengan menahan laba saat ini dalam jumlah yang lebih besar, berarti perusahaan memiliki lebih sedikit uang yang akan tersedia bagi pembayaran dividen saat ini sehingga pada akhirnya akan berdampak terhadap nilai perusahaan.

Dilihat dari robust test model, dimana Ketika variabel control size dihilangkan, menunjukkan hasil pengujian yang konsisten dengan model penelitian utama, dimana struktur modal (DER) berpengaruh positif terhadap nilai perusahaan (PBV). Begitu juga dengan hasil yang 
konsisten di dapat oleh kebijakan dividen (EPS) berpengaruh positif terhadap nilai perusahaan (PBV). Hal ini menunjukkan bahwa hasil penelitian ini dikatakan robust atau kokoh.

\section{PENUTUP}

Berdasarkan hasil analisis dan pembahasan yang telah dilakukan, maka dapat diberikan kesimpulan bahwa struktur modal dan kebijakan dividen berpengaruh positif signifikan terhadap nilai perusahaan pada perusahaan manufaktur sub sektor food \& beverages di bursa efek Indonesia (BEI). Hal ini menunjukkan bahwa semakin tinggi struktur modal yang di gunakan perusahaan dan semakin besar dividen maka semakin tinggi nilai perusahaan. Hal ini menunjukkan bahwa semakin tinggi dividen yang dibagikan kepada investor maka semakin tinggi nilai perusahaan, karena investor akan tertarik akan laba yang ditawarkan oleh perusahaan.

Interaksi antara profitabilitas dan struktur modal berpengaruh positif dan signifikan terhadap nilai perusahaan manufaktur sub sektor food \& beverages di bursa efek Indonesia (BEI). Hal ini menunjukkan bahwa semakin tinggi struktur modal yang di gunakan perusahaan, maka semakin tinggi pula aset yang dimiliki perusahaan, dan akan meningkatkan nilai perusahaan. Interaksi antara profitabilitas dan kebijakan dividen memperlemah nilai perusahaan. Hal ini menunjukkan bahwa semakin tinggi dividen yang diberikan, maka semakin berkurang profit perusahaan yang ada. Jika jumlah dividen dibagikan seluruhnya kepada pemegang saham, maka profit yang ada akan berkurang yang menjadikan nilai perusahaan menurun.

Adapun saran yang dapat disampaikan kepada perusahaan adalah pemilihan dana yang akan digunakan harus memilki ukuran dan perhitungan yang tepa tantara dana yang akan digunakan dengan modal yang ada, perbandingan yang tepat akan memberikan kemudahan bagi perusahaan untuk membayar utang perusahaan. Dalam hal kebijakan deviden, perusahaan harus memperhatikan kondisi harga saham pasar agar, pemberian dividen kepada investor bisa disesuikan, sehingga perusahaan stabil.

\section{REFERENSI}

Abidin, Z., Yusniar, M. W., \& Ziyad, M. (2016). Pengaruh Struktur Modal, Kebijakan Dividen dan Size terhadap Nilai Perusahaan (Studi pada Perusahaan Properti di Bursa Efek Indonesia). JWM (Jurnal Wawasan Manajemen), 3(1), 91-102.

Abdillah, A. (2013). Analisis Pen-garuh Kebijakan Dividen, Kebijakan Hutang, Profitabilitas, dan Keputusan Investasi Terhadap Nilai Perusahaan. Skripsi. Fakultas Ekonomi dan Bisnis Universitas Dian Nuswantoro, Semarang.

Aisjah, Siti. 2012. Strategi Diversifikasi Korporat Penciptaan Nilai Perusahaan. Malang: UB Press.

Amanda, Astrid, dkk. 2012. "Pengaruh Debt To Equity Ratio, Return On Equity, Earning Per Share, dan Price Earning Ratio Terhadap Harga Saham (Studi Pada Perusahaan Food And Beverages Yang Terdaftar Di BEI Tahun 2008-2011)." Malang: Jurnal Universitas Brawijaya.

Brigham, F Eugene and Joel F Houston. 2009. Dasar-Dasar Manajemen Keuangan. Buku Satu Edisi Sepuluh. Jakarta: Salemba Empat.

Fakhruddin, Hendi. 2008. Go Public Strategi Pendanaan Dan Peningkatan Nilai Perusahaan. Jakarta: Gramedia.

Hantono. 2018. Konsep Analisa Laporan Keuangan Dengan Pendekatan Rasio Dan SPSS. Yogyakarta: Deepublish.

Horne, James C. Van dan Wachomicz, John M. Jr. 2001, Fundamental Financial Mangement, New Jersey, Pearson Prentice Hall.

Hermuningsih, Sri. 2012. Pengantar Pasar Modal Indonesia. Yogyakarta: UPP STIM YKPN. 
Hilmi, Abdullah dkk. 2016. "Pengaruh EPS, DER, PER, ROA Dan ROE Terhadap Harga Saham Pada Perusahaan Tambang Yang Terdaftar di BEI Untuk Periode 2011-2013." Banjarmasin: Dinamika Ekonomi.

Husnan, Suad. 2001. Teori Portofolio dan Analisis Sekuritas. AMP YKPN : Yogyakarta

Juhandi, Nendi. 2007. Manajemen Keuangan. Cileungsi: Pelangi Nusantara. 2008. Manajemen Keuangan Lanjutan. Cileungsi: Pelangi Nusantara.

Kohar, A., \& Akramunnas, A. (2017). Pengaruh struktur modal dan kebijakan dividen terhadap nilai perusahaan. Assets: Jurnal Ekonomi, Manajemen dan Akuntansi, 7(1), 1-16.

Mardiyati, Umi, dkk. 2012. "Pengaruh Kebijakan Dividen, Kebijakan Hutang Dan Profitabilitas Terhadap Nilai Perusahaan Manufaktur Yang Terdaftar Di Bursa Efek Indonesia (BEI) Periode 2005-2010.” Jakarta: Jurnal Riset Manajemen Sains Indonesia (JRMSI), Volume 3 Nomor 1.

Maulana, \& Wati, L.N. (2019). Peran Koneksi Politik dan Struktur Kepemilikan dalam Peningkatan Nilai Perusahaan. Jurnal Akuntansi STIE Muhammadiyah Jakarta. Vol. 8 No. 1. 1-13.

Oktaviani, Retro Fuji dan Anissa Amalia Mulya. 2018. "Pengaruh Struktur Modal, Dan Profitabilitas Terhadap Nilai Perusahaan Dengan Kebijakan Dividen Sebagai Moderasi." Jurnal Akuntansi Dan Keuangan FEB Universitas Budi Luhur, Volume 7 Nomor 2 Oktober 2018.

Prastuti, N. K. R., \& Sudiartha, I. G. M. (2016). Pengaruh struktur modal, kebijakan dividen, dan ukuran perusahaan terhadap nilai perusahaan pada perusahaan manufaktur. E-Jurnal Manajemen, 5(3).

Puspitaningtyas. 2017. "Efek Moderasi Kebijakan Dividen Dalam Pengaruh Profitabilitas Terhadap Nilai Perusahaan Manufaktur." Jurnal Akuntansi, Ekonomi dan Manajemen Bisnis, Volume 5 Nomor 2, December 2017, 173-180, E-ISSN: 2548-9836.

Putra, A. N. D. A., \& Lestari, P. V. (2016). Pengaruh Kebijakan Dividen, Likuiditas, Profitabilitas dan Ukuran Perusahaan Terhadap Nilai Perusahaan. E-Jurnal Manajemen, 5(7).

Sartini, L. P. N., \& Purbawangsa, I. B. A. (2014). Pengaruh Keputusan Investasi, Kebijakan Deviden, serta Keputusan Pendanaan terhadap Nilai Perusahaan Manufaktur di Bursa Efek Indonesia. Matrik: Jurnal Manajemen, Strategi Bisnis Dan Kewirausahaan.

Sugiono, Arief dan Edy Untung. 2016. Panduan Praktis Dasar Analisa Laporan Keuangan. Jakarta: Grasindo.

Viandita, dkk. 2013. "Pengaruh Debt Ratio (DR), Price Earning Ratio (PER), Earning Per Share (EPS), Dan Size Terhadap Harga Saham (Studi Pada Perusahaan Industri Yang Terdaftar Di Bursa Efek Indonesia.” Malang: Jurnal Administrasi Bisnis (JAB) Volume 1 Nomor 2 April 2013.

Wati, L. N. 2017. Board of commissioner's effectiveness on politically connected conglomerates: Evidence from Indonesia. Pertanika Journal Social Sciences \& Humanities, 25(S), pp. 255-270.

Wati, L.N. 2018. Metodologi Penelitian Terapan dengan Aplikasi SPSS, EVIEWS, SmartPLS, dan AMOS. Jakarta: Pustaka Amri.

Wati, L.N., Syahdam, G.R., Prambudi, B. (2019). Peran Pengungkapan CSR dan Mekanisme GCG Pada Kinerja Keuangan terhadap Nilai Perusahaan. Ecodemica. Vol. 3 No. 2. Pp. 98-110.

Wati, L. N.; Primiana, H. I.; Pirzada, K.; Sudarsono, R. 2019. Political connection, block holder ownership and performance, Entrepreneurship and Sustainability Issues 7(1): 52-68.

Weston, J. Fred dan Thomas E. Copeland. 1997. Manajemen Keuangan. Jilid 1 dialih bahasakan oleh Jaka Wasana dan Kibrandoko, Binarupa Aksara. Jakarta

Wiagustini, Ni Luh Putu. 2010. Dasar-Dasar Manajemen Keuangan. Denpasar: Udayana University Press. 